\title{
'Organic nannofossils': a new type of palynomorph from the Palaeogene of the North Sea
}

\author{
PETER A. HOCHULI
}

Department of Earth Sciences, Swiss Federal Institute of Technology, Sonneggstr.5, CH-8092 Zürich, Switzerland (e-mail:hochuli@erdw.ethz.ch).

\begin{abstract}
Organic microfossils of regular dodecahedral shape are found in the Palaeogene (Lower Oligocene) of the central and northern parts of the Norwegian North Sea. The shape and structure of these fossils are very similar to coccospheres of the calcareous nannoplankton genus Braarudosphaera. The individual pentagonal plates show the same morphological features as replicas of the inner surface of pentaliths forming calcareous coccospheres. It is the first evidence that a representative of calcareous nannoplankton (Haptophyta, Coccolithophorales) is found to produce acid-resistant organic microfossils. The organic remains might have been produced by an undescribed species of the genus Braarudosphaera or represent an unknown stage in the life cycle of species which normally produce calcareous plates. J. Micropalaeontol. 19:(2): 153-158, December 2000.
\end{abstract}

\section{INTRODUCTION}

During a palynological study of the Oligocene and Eocene sections of numerous wells in the Norwegian sector of the North Sea (location map, Fig. 1), a previously unknown type of palynomorph has been found. Most of the specimens observed in palynological slides represent flattened and collapsed structures consisting of 11-12 very thin, regularly shaped pentagonal plates. Undeformed specimens with a regular dodecahedron shape have been found among the unoxidized organic residue (Pl. 1, figs 6, 9 and Pl. 2, figs 1-7). Isolated plates are very rare and were probably lost during the processing (see description of the method below). The restricted stratigraphic range, the possibly limited regional distribution and most certainly the very thin and translucent structure of the organic dodecahedrons may be responsible for the fact that the described forms have not been documented before. It is quite possible that palynologists unfamiliar with such well-defined geometric forms may have ignored them as artefacts in routine studies.

The described forms show a striking similarity to the calcareous nannoplankton species attributed to the genus Braarudosphaera. The different species of the genus Braarudosphaera are essentially defined by the overall shape of the pentaliths and the form and arrangement of the individual crystals (Perch-Nielsen, 1985; Aubry, 1989). The type species of the genus and best known extant species - Braarudosphaera bigelowii (Gran \& Braarud) Deflandre, 1947 - can be observed in a wide range of marine environments. However, as a very tolerant species surviving under hyposaline as well as hypersaline conditions, it is commonly found in neritic environments. In the fossil record, high abundance of $B$. bigelowi is generally regarded as an indication of marginal marine conditions (Thierstein, 1974, 1976). The genus has a very long stratigraphic range from the Late Jurassic up to the present and the species $B$. bigelowii ranges from the Late Cretaceous until today (PerchNielsen, 1985).

Because there are no long-term cultures of $B$. bigelowil, the life cycle and factors for proliferation of this species are not fully understood. According to Tappan (1980) the coccospheres of Braarudosphaera with tightly adjusted pentaliths seem to posses more characteristics of cysts than of vegetative cells. So far no record of preservable organic-walled stages has been reported.

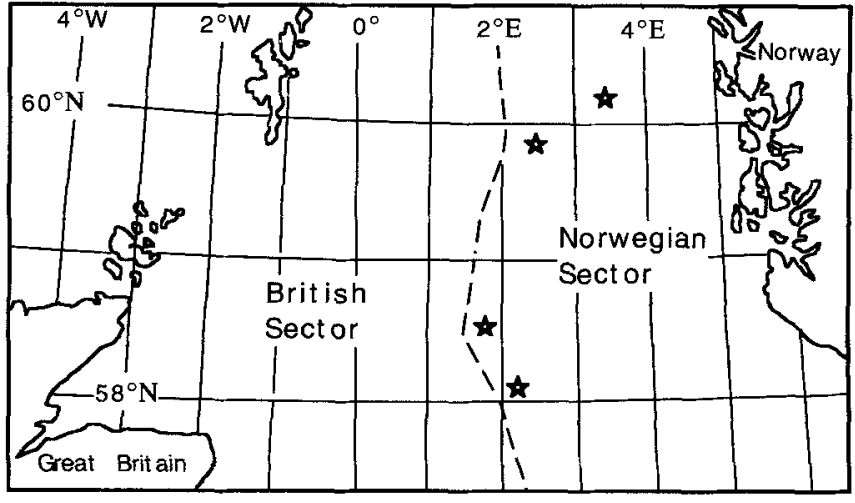

Fig. 1. Location of the wells with records of organic-walled Braarudosphaera.

\section{MATERIAL AND AGE DATING}

The studied material comes from an area of active oil exploration situated between $1^{\circ} 30^{\prime}-3^{\circ} 15^{\prime} \mathrm{E}$ and $58^{\circ} 30^{\prime}-60^{\circ} 30^{\prime}$ $\mathrm{N}$ (location map, Fig. 1). Details of the provenance of the organic dodecahedrons, such as well numbers and sample depths are confidential and cannot be disclosed. The described forms have been recorded in seven wells in the studied area. Several (36) samples of the critical interval have been examined in every well.

Samples containing organic dodecahedrons have been prepared from fine-grained siltstones of the Lark Formation. This formation represents a thick and rather monotonous sequence of siltstones and shales of Early Oligocene age (Knox \& Holloway, 1992), which is generally interpreted to correspond to an outer neritic to upper bathyal environment. Although frequently studied for routine biostratigraphy, no detailed inventory of the palynomorphs of the Lark Formation has been published. To my knowledge no calcareous nannoplankton data have been published from this formation in the studied area.

In the Norwegian North Sea the Early Oligocene sections are of low interest in petroleum exploration; for this reason no cores or sidewall cores were available for this study. All the figured 
P. A. Hochuli
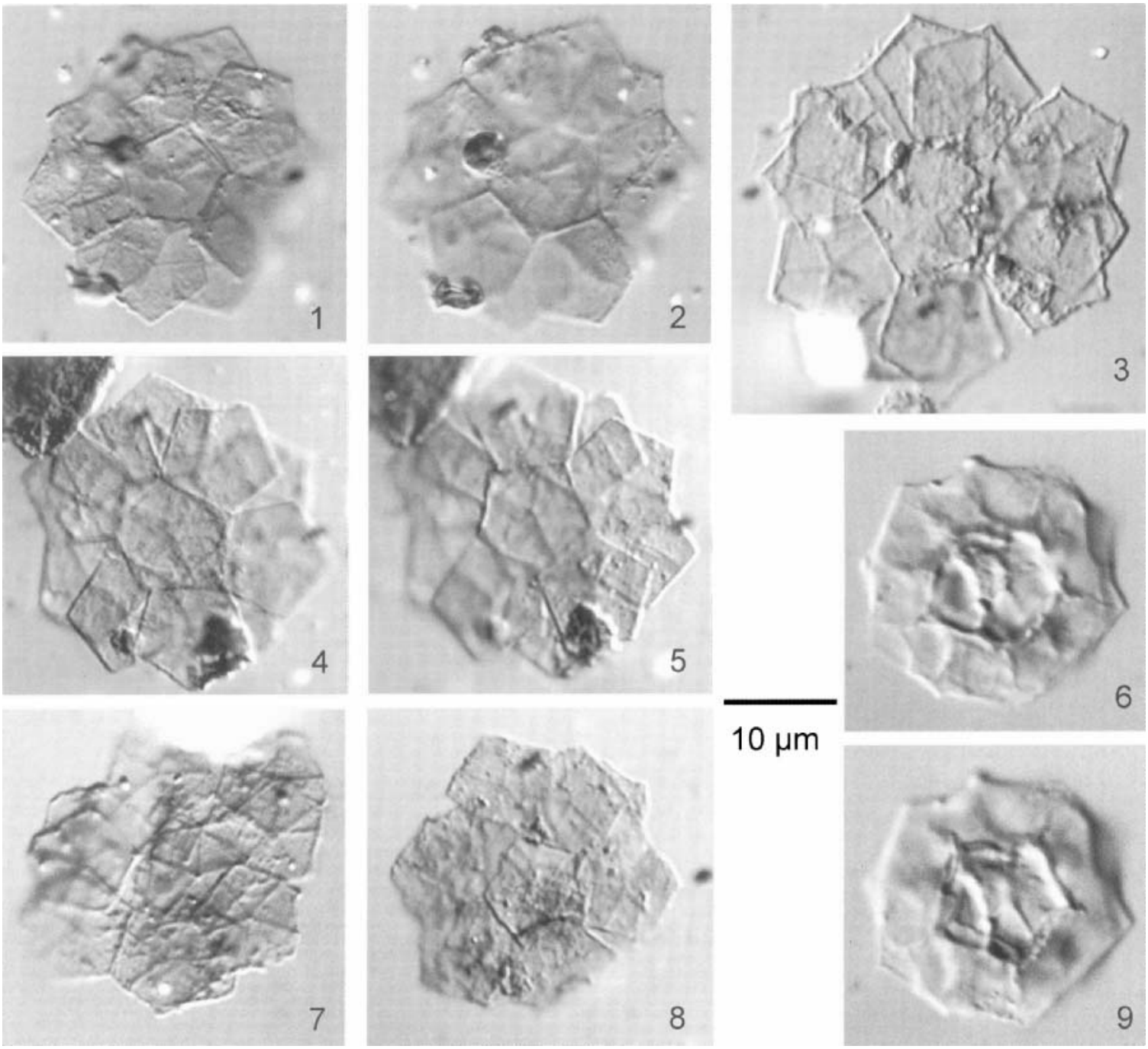

$10 \mu \mathrm{m}$

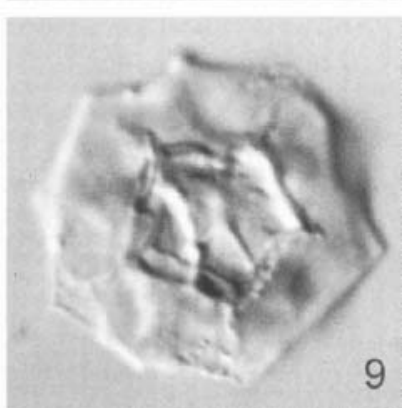

Explanation of Plate 1

Light microscope images of the organic-walled Braarudosphaera from exploration wells of the Norwegian North Sea. Figs 1-5, 7, 8. Flattened specimens from oxidized material (palynological slides). Figs 5, 9. Three-dimensionally preserved specimen from unoxidized material (kerogen slide).

specimens of organic dodecahedrons have been observed in ditch cutting samples only. Hence, their stratigraphic range is constrained only by LAD (last appearance dates) of dinoflagellate cysts present in the same slides. Consequently, the LAD is relatively well dated whereas their first stratigraphic appearance (FAD) is difficult to establish. Apart from regular occurrences in Early Oligocene sections, these forms have been sporadically observed in ditch cutting samples of Palaeocene and Cretaceous age where they are probably caved (downhole contamination). They have never been observed in the numerous sidewall cores or core samples studied from the lower part of the Palaeogene (Middle Eocene - Palaeocene) of the same wells or from other wells in the same area.

The most characteristic dinoflagellate cysts found in the quite rich and well-preserved associated palynomorph assemblages are listed below. For full taxonomic citations of the dinoflagellate cyst species the reader is referred to Williams et al. (1998).

\author{
Adnatosphaeridium multispinosum \\ Areoligera semicirculata \\ Chiropteridium galea \\ Homotryblium plectilum \\ Membranophoridium aspinatum \\ Phthanoperidinium spp. (frequent) \\ $P h$. cf. levimurum \\ Rhombodinium draco \\ Svalbardella cooksoniae \\ Thalassiphora reticulata \\ Wetzeliella symmetrica symmetrica
}

This association is typical for an Early Oligocene age. It can be assigned to the Wetzeliella gochtii zone of Powell (1992), which is interpreted to correspond to the interval of nannoplankton zones NP21-NP23. The high abundance of bisaccate pollen and the relatively reduced diversity of angiosperm pollen found in these samples also represent typical features of the 
lowermost Oligocene of NW Europe.

\section{METHODS}

The studied material was processed according to standard palynological methods, essentially following the technique described by Barss \& Williams (1973). In this process calcite is removed from the sample by treatment with cold hydrochloric acid (technical quality, 37\%). After completion of the reaction the acid is removed and the residue is washed several times with water in order to remove the $\mathrm{Ca}$ ions and to avoid the formation of crystals of calcium fluoride during the subsequent processing. Silicates are removed from the residue with concentrated hydrofluoric acid $(48 \%)$. Since this reaction is carried out without cooling, the samples often reach temperatures of the order of $70^{\circ} \mathrm{C}$. To complete this reaction the samples are placed on a shaker for about 18 hours. After washing with water they are treated with hot concentrated $\mathrm{HCl}$. The residue is then washed several times with water and sieved with a $15 \mu \mathrm{m}$ mesh sieve to eliminate the finest fraction. Part of the remaining organic residue is mounted as a kerogen slide. For stratigraphic studies palynomorphs are further concentrated by removing the more easily soluble organic matter through oxidation with fumic nitric acid applied for one to two minutes. After neutralizing, the residue is stained with fuchsin and mounted as a palynological slide. The described dodecahedrons have been observed in unoxidized, as well as oxidized and stained, organic residues.

The residue of the above-described procedure consists of acidresistant organic matter such as phytoclasts, essentially wood and cuticles, as well as spore-pollen, dinoflagellate cysts and, in the present case, the described dodecahedrons. Using normal bright field microscopy the latter forms can be easily overlooked. Their optical properties and staining behaviour in fuchsin are similar to very thin-walled organic dinoflagellate cysts. For the present study, phase contrast or Nomarsky interference phase contrast has been used. Experience shows that very thin-walled organic microfossils like those described in this paper are most clearly visible in phase contrast.

\section{DESCRIPTION}

Due to the fact that the described remains are organic, the terms used to describe calcareous nannoplankton cannot strictly be applied. However, for the purpose of this paper it does not appear essential to develop a new terminology to describe organic-walled forms. Most specimens consist of 10 to 12 very thin, regularly shaped pentagonal plates. Undeformed specimens forming a regular dodecahedron are very rare and seem to occur more frequently in the unoxidized residues. Most of the specimens observed in the palynological preparations are compressed and the original configuration can be inferred only from the shape and the number of plates. SEM examination of unoxidized residue revealed several specimens with perfect threedimensional preservation (P1. 2, figs 1-7).

The SEM pictures show that the margin of each plate is bent slightly outwards to form a perfectly adjusted contact area between neighbouring plates (P1. 2, figs 1-7). Under high magnification of a light microscope, the edges of the plates appear slightly thickened (Pl. 1). On most of the plates five thin radial lines run from the centre to the sides of the pentagon, intersecting the margins of the corresponding sector at a point slightly offset from the centre point and subdividing the plate into five trapezoidal asymmetric parts. The angles between these lines vary between the extremes of $82^{\circ}$ and $62^{\circ}$. However, most of the measurements cluster close to the regular $72^{\circ}$ angle. Thus the subdivision of the pentagonal plates by fine lines does not correspond to a regular radial symmetry. The subdivision created by the lines offset in relation to the outline of the pentagon suggests rotational symmetry. Regarding the calcareous forms of Braarudosphaera, Tappan (1980) noted that the pentaliths show slight variations in the dimensions of the single crystals, corresponding to a rotational symmetry, a feature that they have in common with many other coccoliths.

The radial lines on the pentagons are at the limit of light microscope resolution. On flattened specimens, superimposed images often mimic additional subdivisions (Pl. 1, figs 3 and 7). Except for these lines, the surface of the plates is smooth or slightly scabrate. A single plate on the specimen illustrated in Plate 2, figs 1, 2 and 7 shows an irregular pattern of contorted lines. The same plate also shows a small pore-like structure. Presently it cannot be determined if these features are due to preservation (artefact) or if they correspond to a specialized area on the surface of the organic dodecahedron. The pore-like structure is similar to the flagellar mark observed on dinoflagellate cysts.

The length of the sides of the pentagon is constant for any given specimen and varies from 8 to $12 \mu \mathrm{m}$ among the 15 measured specimens with an average of $10 \mu \mathrm{m}$. The complete dodecahedrons measure between 15 and $20 \mu \mathrm{m}$ in diameter. The size of the specimens observed in the palynological slides varies according to the degree of flattening. Although the flattened forms suggest that the dodecahedrons collapsed to release the living cell, only one of the four undeformed specimens observed in SEM shows no detached plate ( $\mathrm{Pl}$. 2, fig. 3). One plate is missing on the specimen illustrated in Plate 2, figs 4 and 5 and shows the inner part of the dodecahedron filled with sediment or organic debris. The specimens illustrated in Plate 2, figs 1, 2, and 6 display at least one detached plate to form a slit-like opening. Calcareous coccospheres with one detached pentalith are observed regularly (P1. 2, fig. 8).

\section{DISCUSSION AND COMPARISON}

Size and morphology of the organic-walled dodecahedrons are comparable to the morphology of the extant Braarudosphaera bigelowii (Pl. 2, fig. 8). This species bears pentagonal coccoliths (pentaliths) composed of five asymmetric four-sided calcite crystals. Obviously the living cell of the figured specimen has escaped through an opening formed by the loss of one pentalith. The described organic remains seem to reflect the same pentalith morphology as a carbon replica of calcareous $B$. bigelowii. However, there is no proof of a direct relationship between the organic forms and a particular species of the genus, which are defined based on the form and structure of the pentalith crystals. Although the organic plates reflect the same basic structures as $B$. bigelowii, other species with a similar disposition but a different crystal form must also be considered.

Although $B$. bigelowii is a common extant species, some of its morphological features have not been elucidated. It is, for instance, not clear how the five crystals of the coccolith remain attached to each other. Hay \& Towe (1962) speculated that a 

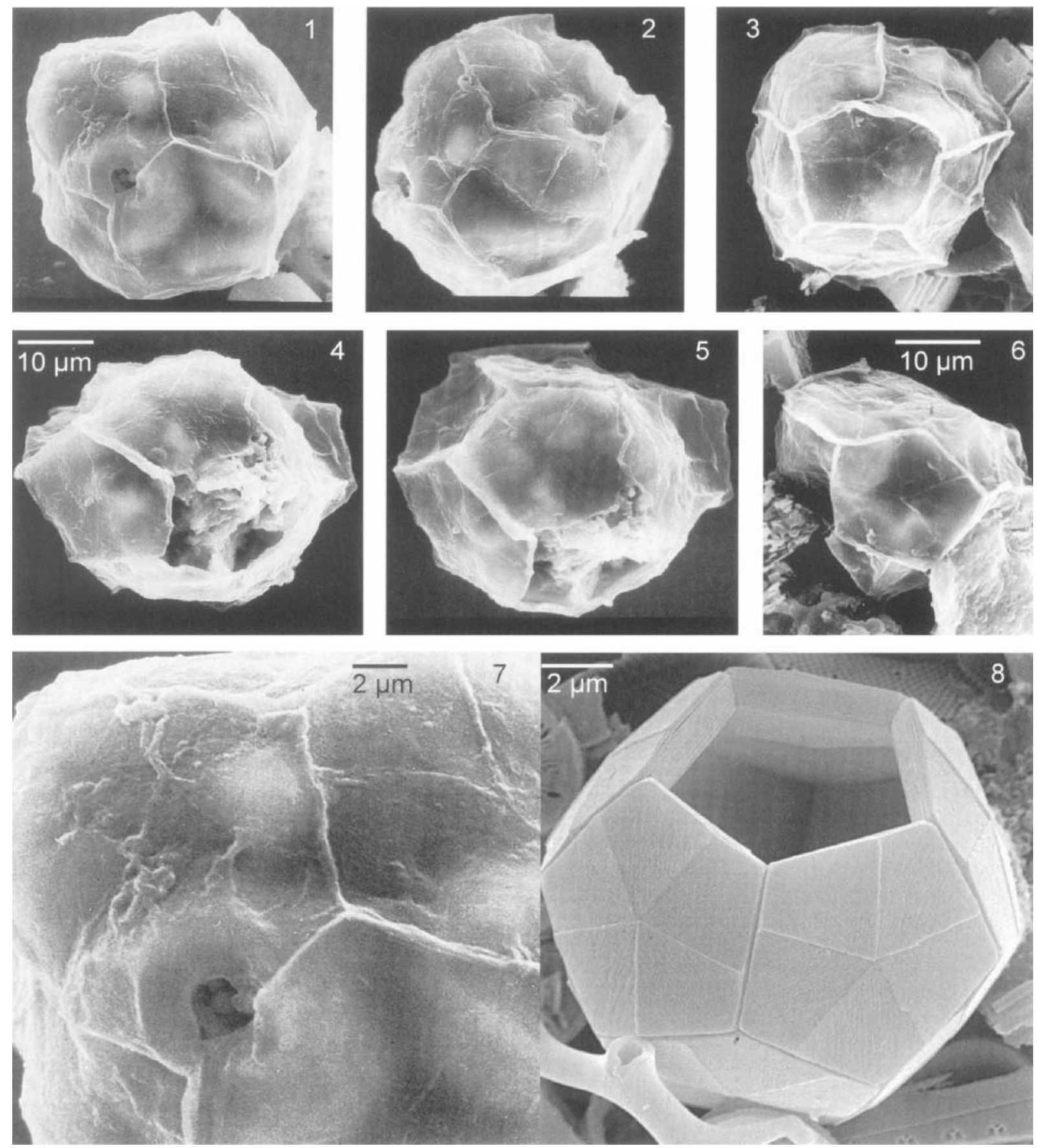

Explanation of Plate 2

SEM images of organic-walled Braarudosphaera. Figs 1, 2. Organic-walled Braarudosphaera viewed from two different angles. Note the opening in the upper part of the dodecahedron. (Scale bar as in Fig. 4.) Fig. 3. Specimen without opening. Note the relatively high contact areas between adjacent plates. (Scale bar as in Fig. 6.) Figs 4, 5. Specimen with one missing plate viewed from two different angles. (Scale bar 10 $\mu \mathrm{m}$ ). Fig. 6. Specimen partly damaged with one detached plate (top left of Figure). (Scale bar $10 \mu \mathrm{m}$ ). Fig. 7. The same specimen as in Figs $1 \& 2$, focusing on the irregularly developed radial lines that appear as distorted, irregular vermiculate sculpture. Note also the pore-like structure on this plate. (Scale bar $2 \mu \mathrm{m}$ ). Fig. 8 . Recent calcareous coccosphere of Braarudosphaera bigelowii (Gran \& Braarud) Defiandre 1947. Mediterranean VICOMED I cruise, Menorca Island station $\left(39^{\circ} 40.5^{\prime} \mathrm{N}, 04^{\circ} 38.6^{\prime} \mathrm{E}\right)$, microphotograph by M. Knappertsbusch. (Scale bar $\left.2 \mu \mathrm{m}\right)$. 
very fine chitinous film might hold them together. The tightly closed structure of coccospheres implies that in the process of reproduction the living cell has to be released. This process can be imagined as a collapse of the dodecahedron or as a release through a predisposed opening. So far, the organic forms with detached single plate openings ( $\mathrm{Pl} .2$, figs $1,2,4,5)$ and the regular observation of coccospheres of $B$. bigelowi with one missing pentalith (M. Knappertsbusch, pers. comm.) suggest that this excysting mode might be common.

In connection with the discovery of the described fossil organic remains of Braarudosphaera, M. Knappertsbusch searched for organic tests in recent material. Sediments with a high number of well-preserved coccospheres of Braarudosphaera bigelowii from the Mediterranean have been dissolved in hydrochloric acid. So far no organic remains have been found (M. Knappertsbusch, pers. comm.). In their preparations for the analysis of trace elements Siesser et al. (1992) also dissolved samples with abundant $B$. bigelowi but no organic residue was observed. The direct observation of the proximal views of the pentaliths of this species does not show any trace of organic matter (J. R. Young, pers. comm.).

The opinion expressed by some colleagues that the described organic remains represent artefacts can be excluded with the following arguments. The observed structures are well defined and the very fine morphological details have been observed on a high number of specimens $(>100)$, involving light microscope and SEM observations. The dodecahedrons have been recorded in seven different wells within the same limited stratigraphic interval. Although processed in the same laboratory, the samples containing numerous specimens have been processed at different times. In the same samples dinoflagellate cysts and other palynomorphs are well preserved and show no particular type of preservation. The wells have been drilled over intervals of several years definitely excluding the possibility that these forms may represent exotic artefacts from the drilling mud.

Except for some imprints of calcareous coccoliths in amorphous organic matter as documented by Lugardon et al. (1991) from the Kimmeridge clay or occasionally in palynomorphs (pers. obs.) there are no records of organically preserved remains of nannoplankton. However, Lentin (1992) described a palynomorph with pentagonal outline from sediments of Eocene to Oligocene age from the Yellow Sea under the generic name Savitrinia Nagy, 1966. Superficially, the material shown by Lentin (1992) seems to be similar to the organic-walled Braarudosphaera. The sharp pentagonal outline and the fact that these forms occur in clusters suggests that they might have originally formed dodecahedrons. In contrast to the described organic-walled Braarudosphaera, they are rather thick-walled with a spongy or perforated structure and show no traces of radial lines. As interpreted from the light microscope image, the central part of these forms seems to bulge and is explained by Lentin (1992) to be double layered, corresponding in this feature to the genus Savitrinia. However, from the published evidence, a comparison with this genus is not convincing, since the two figured specimens (genotype) of $S$. miocenicus Nagy, 1966 (Nagy, 1966, pl. 2, figs 1-8) have a rather thick, probably double-layered wall with a distinct baculate structure. In addition, some of the 5-6 specimens observed by Nagy (1966, p. 40) are not polygonal but 'oval'. Hence, the form and the structure of Savitrinia definitely exclude a comparison with organic-walled Braarudosphaera. The material shown by Lentin (1992) comes from a lacustrine environment documented by ostracods and non-marine dinoflagellates whereas $S$. miocenicus has been described from a sandy clay within the Tortonian coal measures in Hungary.

\section{CONCLUSION}

From the applied processing technique used to extract the described fossils it can be concluded that the described dodecahedrons are organic-walled and have to be regarded as palynomorphs. Based on the shape and structure of the entire fossil, as well as of individual plates, the described organic remains are comparable to coccospheres and to pentaliths of the genus Braarudosphaera. For the moment it cannot be concluded in which part of the life cycle these fossils were produced. Whether the missing plates or the slit-like openings represent mechanical damage or a regular feature cannot be determined from the limited number of SEM observations. The living cell must have escaped from the closed dodecahedron. Hence, the existence of an opening or the collapse of the entire structure can be inferred.

Organic-walled microfossils classified as palynomorphs are produced by very different groups of organism, such as Dinophyta (dinoflagellates), Chlorophyta (Pediastrum, Tasmanites), Fungi, Foraminifera, as well as Bryophyta and higher plants (Embryophyta). This feature was previously unknown for the Haptophyta. Recent studies on calcareous nannoplankton show the heterogeneous biological affinity of this group. According to Horner et al. (1998) the discoasterids presently attributed to calcareous namnoplankton are dinoflagellates. Consequently it seems that the present knowledge of calcareous nannoplankton is insufficient to exclude the possibility that some groups might differ in their affinity, life cycles or mode of reproduction from what is generally known of the Haptophyta. The record of organic-walled remains of Braarudosphaera encourages further research concerning the biology of this group.

\section{ACKNOWLEDGEMENT}

I greatly appreciate H. R. Thierstein, C. Spencer-Cervato (Department of Earth Sciences, ETH Zürich) and M. Knappertsbusch (Museum of Natural History, Basel) for help with the SEM micrographs and the discussion of this material. I would like to thank the management of ESSO Norge and of Exxon Exploration Company for the permission to publish this material. I thank M. Padden for the critical review of the manuscript. The comments of J. Eshet, J. R. Young and of an anonymous reviewer greatly contributed to the clarity of this paper. U. Gerber (Department of Earth Sciences, ETH Zürich) helped with photographic work.

\section{Manuscript received February 2000 Manuscript accepted August 2000}

\section{REFERENCES}

Aubry, M.-P. 1989. Handbook of Cenozoic calcareous nannoplankton. Book 3: Ortholithae (Pentaliths, and others); Heliolithae (Fasciculiths, Spenoliths, and others). Micropaleontology Press, New York. 
Barrs, M. S. \& Williams, G. L. 1973. Palynology and nannofossil processing techniques. Geological Survey Canada, Paper 73-26: 1-25.

Deflandre, G. 1047. Braarudosphaera nov. gen., type d'une famille nouvelle de Coccolithophoridés actuels à éléments composites. Académie des Sciences Paris, Comptes Rendus, Série D, 225: 439-441.

Hay, W. W. \& Towe, K. M. 1962. Electron-Microscope studies of Braarudosphaera bigelowii and some related Coccolithophorids. Science, 137: 426-428.

Horner, R. A., Carstens, M., Gradinger, R., Ikavalko, J. \& Spindler, M. 1998. Discoasters are recent taxa. Norges teknisk-naturvitenskapelige universitet Vitenskapsmuseet, Rapport botanisk serie, 1998-1: 70-71.

Knox, R. W. O'B. \& Holloway, S. 1992. Paleogene of the Central and Northern North Sea. In Knox, R. W. O'B. \& Cordey, W. G. (Eds), Lithostratigraphic nomenclature of the UK North Sea, 1-133. British Geological Survey.

Lentin, J. 1992. Savitrina reveals her secrets in the Orient. American Association of Stratigraphic Palynologists Newsletter, 25/1: 28-29.

Lugardon, B., Raynaud, J.-F. \& Hussone, P. 1991. Données ultrastructurales sur la matière organique amorphe des kérogènes. Palynosciences, 1: 69-88.

Nagy, E. 1966. Investigation into the neogenic microplankton of Hungary. The Palaeobotanist, 15: 38-46.
Perch-Nielsen, K. 1985. Cenozoic calcareous nannoplankton. In Bolli, H. M., Saunders, J. B. 7 Perch-Nielsen, K. (Eds), Plankton stratigraphy, 427-554. Cambridge University Press, Cambridge.

Powell, A. J. 1992. Dinoflagellate cysts of the Tertiary system. In Powell, A. J. (Ed.), A Stratigraphic Index of Dinoflagellate Cysts, 155-252. British Micropalaeontological Society Publication Series, Chapman \& Hall, London.

Siesser, W. G., Bralower, T. J. \& De Carlo, E. H. 1992. Mid-Tertiary Braarudosphaera-rich sediments on the Exmouth Plateau. In von Rad, U., Haq, B. U. et al. Proceedings of the Ocean Drilling Program. Scientific Results, 122: 653-663.

Tappan, H. 1980. The paleobilogy of plant protists. W. H. Freeman and Company.

Thierstein, H. R. 1974. Calcareous nannoplankton - Leg 26, Deep Sea Project. In Davies, T. A., Luyendyk, B. P. et al., Initial Reports deep Sea Drilling Project, Washington (US Government Printing Office) 26: 619-668.

Thierstein, H. R. 1976. Mesozoic calcareous nannoplankton biostratigraphy of marine sediments. Marine Micropaleontology, 1/4: 325-362.

Williams, G. L., Lentin, J. K. \& Fensome, R. A. 1998. The Lentin and Williams index of fossil dinoflagellates 1998 edition. American Association of Stratigraphic Palynologists Contribution Series 34. American Association of Stratigraphic Palynologists Foundation. 